Saule Erkebaeva

ORCID iD 0000-0002-7568-9258

Senior Lecturer of Preschool Education and Social Pedagogy Department,

Institute of Pedagogy and Psychology, Abai Kazakh National Pedagogical University, 13 Dostyk Ave, 050010 Almaty, Republic of Kazakhstan, saule877@mail.ru

\title{
THE DEVELOPMENT OF COMMUNICATIVE ABILITIES OF CHILDREN AT PRESCHOOL AGE
}

The article is devoted to the problem of formation of communicative abilities of preschoolers. It discusses the specific forms and methods of development of communicative abilities of children at preschool age during educational process at preschool, taking into account the patterns of mental and personality development of children of this age. Senior pre-school age is a kind of stepping stone child in the school that determines the need for development of communicative abilities.

Key words: communication skills; forms and methods of development of communicative abilities; pedagogical situation; preschool children; preschool educational institution.

https://doi.org/10.28925/2078-1687.2019.3-4.123128

Introduction. In modern conditions of development of the Kazakhstan society success of each person depends on the ability to make contacts with various people, despite of age and mentality, ability to react quickly to the occurring changes, to analyze information, to make the corresponding decisions and to act according to them.

Preschool childhood, being the age of the initial formation of the child's personality, is an extremely important period of human development. However, currently, according to Volkov B. communicative abilities based on human relations are associated with a lack of kindness, culture, unstable moral criteria in the upbringing of children. Lack of experience in communication of children leads to spontaneous emergence of negative forms of behaviour and unnecessary conflicts. Often children do not know how to make contact properly and tend to choose appropriate ways to communicate with peers by showing their politeness, friendly attitude to them, observe conversational etiquette, listen to a partner (Volkov, Volkova, 2008).

A child, who does not communicate much with his peers, is not accepted by them as a friend, because of the inability to create communication with them, he would feel hurt and rejected, which can lead to low self-esteem, an increase in shyness in making contacts, isolation, the formation of anxiety or, conversely, to excessive aggressive behaviour. The earlier parents will pay attention to this side of the child's life, the less problems he will have in the future life. Concepts of "Communication and development of communicative abilities» of children at preschool age were included in domestic teachers' and psychologists' works, such as: L. Vygotsky, A. Zaporozhets, A. Leontiev, M. Lisina, G. Kravtsova, T. Repina, кazakh psychologists T. Zharykbayev, A. Tazhibaev, G. Autalipova in this regard, it is especially important that $\mathrm{H}$. Sheryazdanova on the basis of the concept of M. Lisina and activity theory of A. Leontiev considers communication as interaction and communicative activity. Moreover, this approach today in our domestic psychological and pedagogical science is the methodological dominant. From the point of preparation of teachers, the position of child psychologists in development of communication process of children is important. Sheryazdanova (1992) on the unification of disparate data on the nature, Genesis, means and mechanisms of communication and the development of «real-acting» methods of training specialists. This allowed the scientist to 
justify the formation of the research position of students and the organization of the pedagogical process on the basis of psychology of communication as a basis for training teachers and psychologists of preschool education.

Also, the scientist-psychologist explaining the conflicting opinions in science about the selective attitude to the «social visual effects of young children focuses on communication as a condition of perception and discrimination of visible effects». Thus, Sheryazdanova (1992) determines the sequences and levels of selectivity of children from birth to the end of preschool age. This fundamentally new approach made it possible to consider from a different angle not only the selective attitude of children to «social» and «non-social» visual influences, the change in the content of the need for communication during preschool childhood, but also the process of forming the foundations of the worldview and orientation of the personality of preschoolers. Thus, the category "Communication of the child» was introduced into the context of ontogenetic development of children and associated with ethical authorities, personal dispositions, the role of an adult in the process of communication as a model for the child, which was later also updated in the studies conducted at the school of H. Sheryazdanova (1992).

Now the theory of the scientist gives opportunity to develop his followers' new aspects, new determinants and predictors of the psychology of communication.

Also, modern specialists in the field of communication of children with adults and peers (G. Kravtsov, E. Kravtsova, E. Smirnova) consider the forms and methods of development of communicative abilities of preschoolers.

The purpose of the article - to characterize the process of formation of communicative abilities of preschoolers, as well as forms and methods of development of their communicative abilities in the educational process of institutions of preschool education, taking into account the patterns of mental and personal development of children of this period of childhood.

The process of formation of communicative abilities of pre-schoolers. In the standard curriculum of preschool education, approved by the order of the acting Minister of Education and Science of the Republic of Kazakhstan dated August 12, 2016 No. 499 «On approval of the standard curriculum of preschool education and training», the content of the standard curriculum is aimed to the formation of motor, communicative, cognitive, creative, social knowledge skills, self-learning skills in young children, the content of the subject "Communication» is aimed to develop of communicative skills, to develop oral speech in various types of children's activities, enrichment of vocabulary, interest in children's literature. In turn, the Standard calls communicative qualities one of the conditions for successful socialization of preschoolers (The standard curriculum of preschool education, 2016). Thus, in the modern conditions of reforming the education system, the problem of formation of communicative abilities is an urgent social and pedagogical problem, since the success of interpersonal interaction with adults and peers depends on its solution and in general - the success of social adaptation of children.

Communication abilities - individual psychological features of the person providing effective interaction and adequate mutual understanding between people in the course of communication or performance of joint activity (Dorokhova, Kudryavtseva, 2013).

According to L. Chernetskaya (2005) communicative abilities include three main components on which they are based and without which they cannot exist. The first component of communicative abilities is the "area of desire», which includes the need for communication, which determines the desire of the child to make contact with others. Without such a desire, communication is simply impossible. The absence or insufficiency of development needs rubbing shoulders and can stem as purely with physiological (violation of functions brain) violations. The appearance of various psychological problems in children is associated with negative factors of the social (primarily family) environment (Chernetskaya, 2005, p. 24).

The second component of communicative abilities - the "area of knowledge» is determined by how much the child has an idea of the norms and rules of effective communication. This knowledge is also formed in the course of interaction with adults, who, by their example, show the child how to make contact with another person, how to maintain a conversation and complete it, how to resolve emerging conflicts (Koroleva, 2014).

The ability to use existing ideas about effective communication - the third (behavioural) component of communication abilities - the 
ability to communicate «area of skills». It includes the ability to target and attract the interlocutor's attention, goodwill, argumentation communication, ability to interest the interlocutor about their opinion and accept his point of view, a skill critical to their own opinion, actions, statements, listening skills, emotional empathy, and resolve conflicts (Dorokhova, Kudryavtseva, 2013, p. 22).

Only in the presence of all three harmoniously developed components we can talk about the presence of a child developed communication abilities. The process of formation of communication abilities in children of senior preschool age largely depends on the organization of various types of children's activities using a variety of forms and methods (Koroleva, 2014).

It is well known that the leading activity of preschool children is playing games. In the game there is a formation of production experience and arbitrary behaviour of the child, his self-realization and socialization (that is, entering into human society), familiarization with communicative culture - the culture of communication. In a group games, primarily, leadership, selfconfidence are shown, organizational skills begin to develop. The main forms of development of communication abilities are story games and games with rules, story-role-playing games. Story games focus primarily on the development of imagination and the development of the ability to understand the other. For games with rules (didactic, desktop, mobile) is characterized by the development of normative regulation, achievement motivation, the desire for willpower and perseverance.

It should be emphasized the possibilities and importance of outdoor games: children learn to act in a team, to obey the General requirements. Children perceive the rules of the game as the law, and the conscious implementation of them forms such qualities of personality as will, self-control, endurance, ability to control their actions and their behaviour in general. Mobile games teach sincerity, mutual aid, camaraderie. By obeying the rules of the games, children practice moral actions, learn to be friends, empathize, help each other. Preschoolers gain invaluable experience of interaction with other people, learn models of social behaviour.

Theatrical games (dramatization games and director's games) are of particular importance for the formation of communication abilities by creating favourable conditions for natural communication with adults and peers, for the development of expressiveness of speech. They affect the social development of the child by understanding the moral implications of the literary work, which is the basis of their content, and due to the collective nature of the majority of children's games, which creates favourable conditions for the development of a sense of partnership, for the development of ways of positive interaction. Pedagogical situation (educating situation) - as a form of development of communication abilities are pedagogical emphasis of children's attention on any conflict, contradiction, conflict, the consequence of which is the analysis of ways of their resolution, overcoming, as well as the direct inclusion of the child in it. The pedagogical situation can be both natural (vital) and artificial. It has a dialogue character that determines the joint solution of children and adults tasks.

The pedagogical situation includes such methods and techniques as: questions; tasks for the description of actions, Affairs, people, positions, etc.; analysis of the causes and consequences of people's actions in various pedagogical situations, game exercises, solving situational problems; exercises in the description of moral concepts, tasks for inventing different versions of fairy tales, stories with moral content, writing endings to stories and fairy tales; didactic games, examining pictures with a consistently developing plot containing moral conflicts, establishing sequences and detecting violations in them. Conversation as a form of joint activity is a dialogical interaction between an adult and a child, aimed at the development of curiosity and activity, the ability to solve intellectual and personal problems, mastering the basic means of communication and ways of interaction. Conversation is a method of cognitive-speech development of children specially planned by the teacher.

Conversations based on literary texts and personal and collective experiences of children predominate in the older preschool years. During conversations on literary works children have an opportunity on the basis of concrete acts of heroes to come to understanding of the maintenance of various norms of morals, to acquire representations about ways of their manifestation, to establish elementary communications and dependences in behaviour and interrelations of characters, to 
recognize their feelings, etc., and also to intensify the estimated activity.

Preschool pedagogics has accumulated a considerable techniques that are used in the process of conversations with children: admiration is a positive thing; emotional identification of child victims of unfair treatment by peers; developing the ability to anticipate possible consequences of unjust actions; the use of rhymed rules of conduct; dialogues with puppets; advancing the success of the group waiting. The use of such forms as quizzes and contests in the senior preschool age implies that the child has a certain social experience of interaction with peers and adults, as well as a basic Outlook.

Preschoolers master a special style of communication during games-quizzes, do not depart from the cognitive content, essentially, control the statements and actions of partners. Participation in competitions continues to develop partnership interaction of children, promotes improvement of their communicative skills. Any competition is a social situation that teaches the child the culture of winning and the culture of losing.

Conclusion. Thus, the formation of communication abilities for preschoolers in the educational process of preschool institutions is carried out in various types of children's activities in the relationship of various forms, methods and techniques. By the older preschool age, the child develops communication skills. This group of skills consists of well-known skills: cooperate, listen and hear, perceive and understand information, speak for yourself. A high level of communication abilities is the key to successful adaptation of a person in any social environment, which determines the practical importance of the formation of communicative abilities from early childhood.

\section{References}

Volkov, B. S., Volkova, N. V. (2008). Psihologiya obsheniya $v$ detskom vozraste [Psychology of communication in childhood]. Saint Petersburg, Russia: Piter (rus).

Dorokhova, T. S., Kudryavtseva, E. O. (2013). Socialno-pedagogicheskaya deyatelnost s detmi s ogranichennymi vozmozhnostyami zdorovya $\mathrm{v}$ doshkolnom obrazovatelnom uchrezhdenii [Social and pedagogical activity with children with disabilities in preschool educational institution]. Bulletin of social and humanitarian education and science, 2, 37-42 (rus).

Koroleva, S. V. (2014). Modelirovanie processa upravleniya kachestvom v doshkolnoj obrazovatelnoj organizacii [Modeling of quality management process in preschool educational organization]. Pedagogical education in Russia, 1, 31-35 (rus).

Ob utverzhdenii Tipovyh uchebnyh programm doshkolnogo vospitaniya i obucheniya. Prikaz i.o. Ministra obrazovaniya i nauki Respubliki Kazahstan ot 12 avgusta 2016 goda № 499 [The standard curriculum of preschool education and training approved by the order of the acting Minister of education and science of the Republic of Kazakhstan dated August 12, 2016 No. 499 «On approval of the standard curriculum of preschool education and training»]. Retrieved from https://zakon.uchet.kz/rus/docs/ V1600014235 (rus).

Bodalev, A. A. (Ed.) (2017). Psihologiya obsheniya. Enciklopedicheskij slovar [Communication psychology. Encyclopedic dictionary]. Moscow, Russia: Kogito-Center (rus).

Chernetskaya, L. V. (2005). Razvitie kommunikativnyh sposobnostej u doshkolnikov [Development of communicative abilities in preschoolers]. Rostov-na-Donu, Russia: Phoenix (rus).

Sheryazdanova, H. T. (1992). Uchite detej obsheniyu [Teach your children to communicate]. Almaty, Kazakhstan: Rauan (rus).

\section{Література}

Волков Б. С, Волкова Н. В. Психология общения в детском возрасте. Санкт-Петербург: Питер, 2008. 272 c.

Дорохова Т. С., Кудрявцева Е. О. Социально-педагогическая деятельность с детьми с ограниченными возможностями здоровья в дошкольном образовательном учреждении. Вестник социально-гуманитарного образования и науки. 2013. № 2. С. 37-40.

Королева С. В. Моделирование процесса управления качеством в дошкольной образовательной организации. Педагогическое образование в России. 2014. № 1. С. 31-34.

Об утверждении Типовых учебных программ дошкольного воспитания и обучения. Приказ 
и.о. Министра образования и науки Республики Казахстан от 12 августа 2016 года № 499.

URL: https://zakon.uchet.kz/rus/docs/V1600014235 (дата звернення: 3.09.2019).

Психология общения. Энциклопедический словарь / А. А. Бодалев (ред.). Москва: КогитоЦентр, 2011.600 c.

Чернецкая Л. В. Развитие коммуникативных способностей у дошкольников. Ростов-на-Дону: Феникс, 2005. 256 с.

Шерьязданова Х. Т. Учите детей общению. Алматы: Рауан, 1992. 202 с.

\title{
РОЗВИТОК КОМУНІКАТИВНИХ ЗДІБНОСТЕЙ У ДІТЕЙ СТАРШОГО ДОШКІЛЬНОГО ВІКУ
}

\author{
Еркебаєва Сауле, \\ старший викладач кафедри дошкільної освіти та соціальної педагогіки, \\ Інститут педагогіки і психології, \\ Казахський національний педагогічний університет імені Абая, \\ просп. Достик, 13, 050010 Алмати, Республіка Казахстан, saule877@mail.ru
}

Статтю присвячено проблемі бормування комунікативних здібностей дітей старшого дошкільного віку. Комунікативні здібності визначено як індивідуально-психологічні особливості особистості, що забезпечують ебективну взаємодію і адекватне взаєморозуміння між людьми в процесі спілкування або виконання спільної діяльності. У статті розглядаються конкретні форми і методи розвитку комунікативних здібностей у дітей старшого дошкільного віку в освітньому процесі закладів дошкільної освіти, щзо враховують закономірності психічного і особистісного розвитку дітей иього періоду дитинства. Старший дошкільний вік $є$ свого роду сходинкою для переходу дитини до школи, що визначає необхідність розвитку комунікативних здібностей. Діти старшого дошкільного віку є суб'єктами комунікативної діяльності, активними ї носіями. Комунікативні здібності включають три сфери: сфера бажань, сфера знань і сфера умінь. Поява довільності управління власною поведінкою в спілкуванні забезпечує можливість бормування у дітей комунікативних умінь. Аналіз літератури $і$ вивчення практичного досвіду дозволили провести дослідження комунікативних умінь дошкільнят через гру. Основними формами розвитку комунікативних здібностей є сюжетні ігри, ігри з правилами, сюжетно-рольові ігри.

Структурними компонентами комунікативної діяльності є предмет спілкування, а також партнер по спілкуванню як суб'єкт. Будь-який суб'єкт спілкування повинен володіти комунікативними навичками для успішності в комунікативної діяльності. Комунікативні навички - це здатність людини використовувати засоби спілкування в умовах розв'язання комунікативних завдань на основі набутих знань і умінь.

Ключові слова: діти старшого дошкільного віку; заклади дошкільної освіти; комунікативні здібності; педагогічна ситуація; форми і методи розвитку комунікативних здібностей.

\section{РАЗВИТИЕ КОММУНИКАТИВНЫХ СПОСОБНОСТЕЙ У ДЕТЕЙ СТАРШЕГО ДОШКОЛЬНОГО ВОЗРАСТА}

\author{
Еркебаева Сауле, \\ старший преподаватель кафедры дошкольного образования и социальной педагогики, \\ Институт педагогики и психологии, \\ Казахский национальный педагогический университет имени Абая, \\ просп. Достык, 13, 050010 Алматы, Республика Казахстан, saule877@mail.ru
}

Статья посвящена проблеме формирования коммуникативных способностей дошкольников. Коммуникативные способности определены как индивидуально-психологические особенности тичности, обеспечивающие эффективное взаимодействие и адекватное взаимопонимание между людьми в процессе общения или выполнения совместной деятельности. В статье 
рассматриваются конкретные формы и методы развития коммуникативных способностей $у$ детей старшего дошкольного возраста в образовательном процессе учреждений дошкольного образования, учитывающие закономерности психического и тичностного развития детей этого периода детства. Старший дошкольный возраст является своего рода ступенькой для перехода ребенка в иколу, что определяет необходимость развития коммуникативньх способностей. Дети старшего дошкольного возраста являются субъектами коммуникативной деятельности, активными ее носителями. Коммуникативные способности включают три сферь: сферу желаний, сферу знаний и сферу умений. Появление произвольности управления собственным поведением в общении обеспечивает возможность формирования у детей коммуникативных умений. Анализ титературы и изучение практического опыта позволили провести исследования коммуникативных умений дошкольников через игру. Основными формами развития коммуникативных способностей являются сюжетные игры, игры с правилами, сюжетно-ролевые игры.

Ключевые слова: дети старшего дошкольного возраста; коммуникативные способности; педагогическая ситуачия; формы и методы развития коммуникативных способностей; учреждения дошкольного образования.

Стаття надійшла до редакиії 05.10.2019 Прийнято до друку 31.10.2019 